\title{
SDR, the International Currency for the European Development Plan with Africa ${ }^{1}$
}

\author{
Robert Triffin International
}

This summer a consensus was reached on a mix of policies that can effectively address the emergencies looming over the Mediterranean, turning them into opportunities. In Europe, foreign and security policy, the development Plan with Africa and immigration are increasingly acknowledged as being interconnected, as shown in particular by the launch of the Investment Plan promoted by the European Commission thanks also to the impetus given by the High Representative for Foreign and Security Policy Federica Mogherini. Even at the international level - as evidenced by the indications of the G20 meeting held in Hamburg under the Angela Merkel's Presidency - the priority of African development plays a central role.

The "European Plan with Africa" will cover primarily energy (mainly from renewable sources), water (from deep reservoirs and desalination plants) and technical and professional training. This means networks that must be able to cross pacified and safe territories through the sharing of the EU Global Strategy by part of African countries and their supranational organisations.

Alongside the European plan, which concerns primarily the Mediterranean and sub-Saharan and Saharan Africa, the Chinese plan will also develop, aiming at the development of the African countries facing the Indian Ocean through the Silk Road. India will become more and more involved in this process while the ambitions of the earlier key players, such as the UK, the United States and Russia will remain active.

The financial flows involved will be substantial both for the financing of investments and for the related debt service. The European Fund for Sustainable Development, the operational arm of the European Investment Plan proposed by the Commission in September 2016, will ensure that public and private funds will be mobilised to trigger $€ 88$ billion worth of investments. The model that can guarantee the return of credits and avoid the excessive burden of debts (as has too often been the case with loans in dollars) must be studied in time, i.e. immediately. The central element of any choice is the currency in which credits and debts, costs and revenues are expressed. The more common the currency is to a country's balance sheets, the lower the exchange-rate risk. The more common the currency is to the different parties involved, the greater the chances of cooperation and risk sharing are, with respect to the potential for conflicts. The more common the currency is to different areas of activity, the greater the possibility of risk reduction. The more common the currency is, the less it is subject to the monetary policy and the interests of an issuing State.

After the creation of the euro and with the ongoing internationalisation process of the 
renminbi, the international monetary system has been going through the transition from the dollar standard to a multi-currency system. Three major currencies (dollar, euro and renminbi) and two other less widely used currencies (yen and pound), in addition to constituting the reference in their respective monetary zones, form now the SDR basket. Therefore, it is to the latter that the system must be pegged, in particular in the case of the European Plan with Africa.

The SDR as a unit of account (for economic statistics, financial statements and quotations) can be compared to a vehicular language of numbers, which is essential to prevent a dollar gain from looking like a loss in euro or renminbi, and vice versa. Price volatility in terms of SDRs is less than that in terms of individual currencies. Furthermore, with specific reference to two North African countries that are crucial to the trinomial safety-immigration-development, it should be considered that:

- The Libyan dinar has been officially pegged to the SDR since 1986, when it abandoned the pegging to the dollar;

- Egypt quotes in SDRs the transit permits in the Suez Canal, one of the most important revenues of the country.

In 1975, OPEC decided, after the default of the dollar convertibility into gold announced by President Nixon in August 1971, to quote oil in SDRs. The subsequent agreement reached between the US and Saudi Arabia imposed the dollar as the reference currency, and resulted in the disorderly fluctuation of the oil price. Some countries also tried to fix the oil price in a more stable currency, such as the euro ${ }^{2}$.

Extending the use of the SDR as a unit of account is not the IMF's responsibility (but it has already adopted it, as well as the Bank for International Settlements (BIS) in Basel).
It will be up to individual users (states, institutions, banks, associations) to decide to use them in accounting, the quotation of raw materials or financial statistics, as China has already started doing.

The issue of SDR-denominated financial instruments on the market (M-SDR) for the financing of investment under the Plan with Africa requires a convenience for the issuer and the subscribers, and the formation of a secondary market. And also a clearinghouse, that could be provided by the BIS, as occurred already for the ECU on the request of the Association of Banks that promoted its usage. The issuers would be primarily the European Investment Bank (EIB), multinational banks and regional development banks, and certainly the World Bank, which for the first time issued SDR bonds for China (see Triffin International's SDR Note No. 2). The road would thus be open for the banking system's intervention. There would be many subscribers among the managers of big portfolios (insurance companies, pension funds and others) that today, in the presence of abundant liquidity, do not find an offering of sufficiently attractive securities for the long term (so that the excess of demand results in a value-increase of existing assets, i.e. in financial "bubbles").

In the 1980s, the market for ECU-denominated financial instruments was a great success, and contributed positively to the decision to switch from the basket (ECU) to the single currency (euro). However, in the same decade the SDR deposit and loan market was very weak. The main reason for the different level of appreciation of the two instruments lies in the perception that markets had of the European willingness to move towards a closer integration (the creation of the European Monetary System and the ECU in 1978), and at the same time of the US's open hostility towards the implementation of the second amendment to the Articles of the IMF which, inspired by 
Robert Triffin, contains a commitment to making the SDR the"main reserve asset of the international monetary system".

The SDR, just like the ECU, is technically a derivative, because its value derives from that of the currencies composing it. However, it is a derivative that has the potential to take the place of the currencies it derives from, in the event of a financial disaster such as that of 2007-2008. For this to become possible and for the markets to start to believe in it as of now, a political signal (difficult to achieve at this stage, given the difficulties posed even recently by the American Congress in ratifying measures that strengthen multilateral bodies such as the UN, the WTO or the IMF) is unnecessary. However, the demand for the implementation of the second amendment needs to be maintained. Meanwhile, some "technical" steps may be useful, aimed at making the future unification of the M-SDR and O-SDR markets (official SDRs used by central banks as reserve instruments) possible, in order to foster market confidence and the consequent obligation to respect it. A global "lender of last resort" does not exist, but it can exist, hence it will exist, being one of those predictions that in case of serious international financial crisis leaves no alternative but to self-realize.

The official SDR (O-SDR), as the IMF stresses, is a unique reserve instrument among the international reserve assets, because of two features that distinguish it from any other: 1) it does not accumulate through a surplus in any balance of payments, but is allocated on the basis of the quotas of each country in the Fund; 2) it does not constitute a debt of any specific economy, but rather represents the potential right to obtain freely usable currencies of other member countries.

There is a long way to go before this basket has an Issuer endowed with the necessary powers to fulfill the responsibility to do "whatever it takes" if necessary. However, this road has been taken decisively by the IMF leaders, first Dominique Strauss-Kahn and then Christine Lagarde. Since markets"sense" and "discount", the prospect should be kept determinedly alive in order for the SDRs to finance the Plan with Africa. 